\title{
Postoperative Study of Bone Gain in Mandibular Alveolar Bone Reconstructed with Screw-Guided Bone Regeneration Technique and Porcine-Derived Xenograft in 42 Edentulous Patient Candidates for Implant-Prosthetic Therapy
}

\author{
Doriana Agop-Forna ${ }^{1}$, Roland Törok ${ }^{2, *}$, Bianca Törok ${ }^{2}$, Raluca Dragomir ${ }^{1, *}$, David M. Dohan Ehrenfest ${ }^{3}$, \\ Cristina Dascălu ${ }^{1}$ and Carmen Gabriela Stelea ${ }^{1}$ \\ 1 Faculty of Dental Medicine, UMF “Grigore T. Popa”, University Street, No.16, 700115 Iași, Romania; \\ doriana.agop-forna@umfiasi.ro (D.A.-F.); cristina.dascalu@umfiasi.ro (C.D.); carmenstelea@umfiasi.ro (C.G.S.) \\ 2 Implant Institute Törok, 1712 Tafers, Switzerland; drbianca.toeroek@gmx.de \\ 3 Dental Clinic of the Throne, 75000 Paris, France; ehrenfest@me.com \\ * Correspondence: roland.toeroek@gmx.de (R.T.); ralucadragomir@umfiasi.ro (R.D.)
}

check for updates

Citation: Agop-Forna, D.; Törok, R.; Törok, B.; Dragomir, R.; Ehrenfest, D.M.D.; Dascălu, C.; Stelea, C.G. Postoperative Study of Bone Gain in Mandibular Alveolar Bone Reconstructed with Screw-Guided Bone Regeneration Technique and Porcine-Derived Xenograft in 42 Edentulous Patient Candidates for Implant-Prosthetic Therapy. Appl. Sci. 2021, 11, 9826. https://doi.org/ 10.3390/app11219826

Academic Editor: Bruno Chrcanovic

Received: 25 September 2021

Accepted: 19 October 2021

Published: 21 October 2021

Publisher's Note: MDPI stays neutral with regard to jurisdictional claims in published maps and institutional affiliations.

Copyright: (c) 2021 by the authors. Licensee MDPI, Basel, Switzerland. This article is an open access article distributed under the terms and conditions of the Creative Commons Attribution (CC BY) license (https:/ / creativecommons.org/licenses/by/ $4.0 /)$.

\begin{abstract}
This study aimed to test whether alveolar bone gain (width and osteodensity) in mandible implant sites, augmented by the screw-guided bone regeneration (S-GBR) technique and the porcinederived xenograft, differ from that of the mandible sites reconstructed with S-GBR and the bovinederived xenograft. Materials and method. A total of 42 edentulous patients (mean age $54.60 \pm 14.90$ ) were randomly divided into a test group (S-GBR + porcine-derived xenograft) and a control group (S-GBR + bovine-derived xenograft). The immediate implants were placed simultaneously with grafting procedures. The implant site width was measured before teeth extractions and 6 months after the augmentation procedures. Osteodensity bone values were evaluated immediately after the implant placement and at 6 months follow-up. The CBCT sections and Sidexis XG/DVT (Densply/Sirona) software were used to evaluate the changes of the width in the augmented alveolar bone. The NNT Viewer/CT (NewTom) software was used to record the osteodensity changes. Statistical comparisons between the groups were performed by the Mann-Whitney and $t$-tests (significance level $p<0.05$ ). Results. The mean values of the bone gain at 6 months follow-up (control group vs. test group) were as follows: width $(4.107 \mathrm{~mm}$ vs. $4.1624 \mathrm{~mm})$; osteodensity $(276.83 \mathrm{HU}$ vs. 254.24 HU). The statistical analysis found the absence of statistically significant differences between the two groups regarding the bone gain (width and osteodensity) at 6 months after the augmentation and the immediate implant placement. Conclusions. The horizontal bone and osteodensity gains in the porcine-derived group were similar and without significant statistical differences when compared with the implant sites reconstructed with the bovine-derived xenografts group at 6 months postoperatively. The reconstruction of the mandibular alveolar bone by the S-GBR technique and the porcine-derived xenografts is a valid bone regeneration strategy for edentulous patients with moderate/severe horizontal resorption of the mandibular alveolar bone.
\end{abstract}

Keywords: dental implants; bone resorption; S-GBR; xenograft; bone gain

\section{Introduction}

Implant-prosthetic treatment of edentulous patients has now become a therapeutic approach with reliable functional and aesthetic results [1]. Specialists in implantology face high requirements and expectations of patients on the rehabilitation of functions and aesthetics, while an increased share of implant sites are affected by alveolar bone resorption. At the level of the mandibular areas, the insertion of short or small diameter dental implants at the level of the implant sites with severe resorption does not allow for the adequate reconstruction of the alveolar ridge volume and morphology and reduces the success rate of implant-prosthetic restorations [2]. A functional and stable prosthetic 
implant-mandibular restoration with bone resorption can be compromised in the long term due to the shape and orientation of the residual alveolar bone, improper intermaxillary relationships, and the presence of the inferior mandibular nerve. Implantology and alveolar bone regeneration have always been intertwined fields [3]. Bone regeneration involves histological, morphological, and biological processes induced by both local and recruited cells in association with inflammatory processes, and the formation of the fibrous tissue and bony callus [3]. Today, the alveolar ridge reconstruction is a procedure used in one in four implant sites [4]. It is estimated that up to $50 \%$ of all implant procedures performed in the coming years will involve the use of bone grafts [5]. In this context, the reconstruction of the implant sites through the various guided bone regeneration techniques is an important stage of the implant-prosthetic treatment to restore the aesthetic parameters and the optimal functioning of the stomatognathic system [6,7]. In the case of the resorbed mandibular ridges, the high density and low vascularization of the mandibular cortical bone can impede the efficient alveolar reconstruction and bone tissue regeneration processes [8]. Oral surgeon experience, augmentation technique, and the category of the graft materials are all factors that contribute to the success of the grafting procedure [9]. A wide range of bone regeneration techniques (e.g., guided bone regeneration, distracting osteogenesis, and alveolar ridge division techniques) are used to restore the volume and morphology of the mandibular alveolar ridges [10,11]. Considering the difficulties related to the maintenance of the stability of the grafted areas affected by severe horizontal and vertical resorptions, Screw-Guided Bone Regeneration (S-GBR) ensures tenting mechanisms that can prevent the collapse of the soft tissues and of bone resorption [12]. S-GBR uses a membrane that delimitates the regenerative bone compartment supported by osteosynthesis screws or dental implants. In our dental practice, we applied the S-GBR technique mostly to patients with anterior and posterior mandibular severe horizontal resorption by using a combination of autogenous bone and xenograft materials, and resorbable collagen membranes. In a recent study with 24 months follow-up, we demonstrated the validity and effectiveness of this technique when used with a bovine-derived xenograft [13]. Despite the numerous studies investigating the alveolar bone augmentation with xenografts of bovine origin, only a few have investigated the predictability and stability of the functional and aesthetic outcome following alveolar bone regeneration procedures with porcine-derived xenografts. A research group has highlighted the fear of patients regarding the possibility of transmitting bovine spongiform encephalopathy (BSE) with degenerative effects in the human brain through xenografts of bovine origin [14]. The risk of foreign body reaction, at intervals of 2 to 10 years, must also be considered for bovine xenografts due to the absence of the biodegradation of the inorganic particles [15]. Other benefits of the porcine-derived xenografts are the similar anatomical, physiological, and genetic structure to human bone tissue, and the low risk of transmission of diseases from pig to human [16,17].

This study aimed to test whether alveolar bone gain (width and osteodensity) in mandible implant sites, augmented by the S-GBR technique and the porcine-derived xenograft, differs from the mandible sites reconstructed with the S-GBR and bovinederived xenograft.

\section{Materials and Method}

\subsection{Patients Selection Study Design}

The prospective cohort study was conducted at the Implant Institute Török (Nuernberg, Germany) between December 2018 and May 2020. The study adhered to the ethical values of the Declaration of Helsinki and received the approval of the ethics committee of UMF "Grigore T. Popa", Iași, Romania (Nr.10833). Among the patients who visited the dental clinic, 42 edentulous patients (mean age 54, $60 \pm 14,90$; age 40-79) were selected. All patients involved in the study received information about the objectives of the research and gave informed consent. Inclusion criteria (test group) were as follows: age > 18 years; partially edentulous posterior and anterior mandible; moderate or severe horizontal and vertical resorption of ridges; treatment with fixed implant-supported prosthesis. Exclusion 
criteria were as follows: history of untreated periodontal disease; history of smoking, alcohol, drugs consumed; immunosuppression; decompensated metabolic diseases; pregnancy; history of bisphosphonates therapy; severe bruxism; noncompliant patients. The selected patients were grouped as follows:

- Test group ( $\mathrm{n}=20 ; 36$ implants sites): implant sites augmentation with S-GBR technique and porcine-derived xenograft THE Graft (Purgo Biologics, Seongnamsi, Korea);

- Control group ( $\mathrm{n}=22 ; 50$ implants sites): implant sites augmentation with S-GBR technique and bovine-derived xenograft CompactBone B (Dentegris GmBH, Rheinberg, Germany).

The characteristics of the test and control groups are shown in Table 1. The components of the study design (population, intervention, comparison, and outcomes) are shown in Table 2.

Table 1. Characteristics of test and control group.

\begin{tabular}{cccc}
\hline & $\begin{array}{c}\text { Test Group } \\
\text { (S-GBR + } \\
\text { Bovine-Derived Xenograft) }\end{array}$ & $\begin{array}{c}\text { Control Group } \\
\text { (S-GBR + } \\
\text { Porcine-Derived Xenograft) }\end{array}$ & Total \\
\hline N of subjects (Ns) & $20(47.6 \%)$ & $22(52.4 \%)$ & 42 \\
N of sites (Ni) & $36(41.9 \%)$ & $50(58.1 \%)$ & $86(100.0 \%)$ \\
Age groups & $16(44.4 \%)$ & $24(48.0 \%)$ & $40(46.5 \%)$ \\
age 40-59, Ni (\%) & $20(55.6 \%)$ & $26(52.0 \%)$ & $46(53.5 \%)$ \\
age 60-79, Ni (\%) & $16(44.4 \%)$ & $24(48.0 \%)$ & $40(46.5 \%)$ \\
Gender & $20(55.6 \%)$ & $26(52.0 \%)$ & $46(53.5 \%)$ \\
M, Ni (\%) & $10(27.8 \%)$ & $16(32.0 \%)$ & $26(30.2 \%)$ \\
F, Ni (\%) & $26(72.2 \%)$ & $34(68.0 \%)$ & $60(69.8 \%)$ \\
Dental group & Anterior, Ni (\%) & & \\
Posterior, Ni (\%) &
\end{tabular}

$\mathrm{N}$-number; Ns-number of subjects; $\mathrm{Ni}$-number of implant sites (dental implants).

Table 2. Study design (PICO). Components.

\begin{tabular}{ccc}
\hline Component & \multicolumn{1}{c}{ Description } \\
\hline Population (P) & $\begin{array}{l}\text { Mandibular edentulous patients requiring } \\
\text { alveolar bone grafting and implant-prosthetic therapy }\end{array}$ \\
\hline Intervention (I) & 1. & $\begin{array}{l}\text { Control group: Alveolar bone augmentation by S-GBR technique with } \\
\text { bovine-derived xenograft (CompactBone). Immediate implant placement. } \\
\text { Test group: Alveolar bone augmentation by S-GBR with porcine-derived } \\
\text { xenograft (Purgo). Immediate implant placement. }\end{array}$ \\
\hline Comparison (C) & 1. & $\begin{array}{l}\text { Intra-group: gender; age group; location } \\
\text { Inter-groups: Control (S-GBR + bovine-derived xenograft) vs. Test (S-GBR + } \\
\text { porcine-derived xenograft) }\end{array}$ \\
\hline Outcome (O) & Bone gain at 6 months follow-up (width and osteodensity) \\
\hline
\end{tabular}

\subsection{Description of Surgical Protocol}

The same surgeon (T.R.), with over 20 years of experience in alveolar bone augmentation techniques and implant-prosthetic therapy, performed the S-GBR technique and the immediate implant placement. For all patients, systemic antibiotics were given prophylactically preoperatively and at 4 days postoperatively. The surgical procedures for the test group and the control group were as follows (Table 3):

(a) Dental implants placement simultaneously with alveolar augmentation by S-GBR technique (mixture of autogenous bone with autogenous bone 90:10; porcine pericardial collagen membrane) (test group); 
(b) Dental implants placement simultaneously with alveolar augmentation by S-GBR technique (mixture of bovine xenograft with autogenous bone 90:10; porcine pericardial collagen membrane) (control group).

Table 3. Operatory protocol in S-GBR technique and immediate implantation.

\begin{tabular}{|c|c|c|c|}
\hline No. & Procedure & Instruments and Materials & Role \\
\hline 1. & Local anesthesia & $\begin{array}{l}\text { Ultracain DS-Forte } \\
\text { (Sanofi, Germany) }\end{array}$ & $\begin{array}{l}\text { Ensure patient and } \\
\text { operator comfort }\end{array}$ \\
\hline 2. & $\begin{array}{l}\text { Full-thickness flaps in the } \\
\text { alveolar surgical areas }\end{array}$ & $\begin{array}{c}\text { DeveMed GmbH, } \\
\text { (Tuttlingen, Germany) }\end{array}$ & Opened surgical field \\
\hline 3. & $\begin{array}{l}\text { Immediate implant placement } \\
\text { (length 10-13 mm, } \\
\text { diameter 3.5-4.5 mm) }\end{array}$ & $\begin{array}{l}\text { BioSTI implants (Tafers, Swiss) } \\
\text { Dentium implants (South Korea) }\end{array}$ & \\
\hline 4. & $\begin{array}{l}\text { Periosteal incisions in } \\
\text { flaps areas }\end{array}$ & $\begin{array}{c}\text { Aesculap AG } \\
\text { (Tuttlingen, Germany) }\end{array}$ & $\begin{array}{l}\text { The closure of the flaps } \\
\text { without tension }\end{array}$ \\
\hline 5. & $\begin{array}{l}\text { Osteosynthesis screws ( } 1.5 \mathrm{~mm} \\
\text { diameter, } 8 \mathrm{~mm} \text { length) } \\
\text { insertion on the buccal face of } \\
\text { the bone areas (in } 45^{\circ} \text { angle to } \\
\text { the alveolar ridge) }\end{array}$ & $\begin{array}{c}\text { Implantology kits } \\
\text { Synthes GmbH, } \\
\text { (Zuchwil, Switzerland) } \\
\text { DeveMed GmbH, } \\
\text { (Tuttlingen, Germany) }\end{array}$ & $\begin{array}{l}\text { Maintain the space for the } \\
\text { bone regeneration } \\
\text { compartment }\end{array}$ \\
\hline 6. & $\begin{array}{l}\text { The exposed bone surface area } \\
\text { will be covered with a small } \\
\text { layer of autologous bone, } \\
\text { followed by the porcine/bovine } \\
\text { xenograft near to the } \\
\text { osteosynthesis screw head. } \\
\text { The grafted area will be covered } \\
\text { with resorbable porcine } \\
\text { pericardial membrane }\end{array}$ & $\begin{array}{c}\text { Autogenous bone } \\
\text { Bovine xenograft CompactBone, } \\
\text { (Dentegris GmbH, Germany) } \\
\text { Porcine xenograft Purgo (Purgos } \\
\text { Biologics, Seongnam-si, Korea) } \\
\text { Porcine pericardial tissue } \\
\text { membrane BoneProtect Membrane } \\
\text { (Dentegris GmbH, Germany) }\end{array}$ & $\begin{array}{l}\text { Isolated and protected graft in } \\
\text { front of the cells from the } \\
\text { gingival tissue. Promotion of } \\
\text { the gingival healing. Protect } \\
\text { the surgical site from gingival } \\
\text { dehiscence in the next } \\
\text { 3-4 months. Reconstruction of } \\
\text { the lateral alveolar bone area }\end{array}$ \\
\hline 7. & Surgical site suture & $\begin{array}{c}\text { Nonresorbable sutures } \\
\text { (polypropylene 5.0, } \\
\text { Hu-Friedy, USA) }\end{array}$ & $\begin{array}{l}\text { Protection for the } \\
\text { reconstructed bone and } \\
\text { peri-implant soft tissues }\end{array}$ \\
\hline 8. & $\begin{array}{l}\text { Postoperative care (7 days): } \\
\text { antibiotherapy, analgesics, oral } \\
\text { cavity rinsing with } \\
\text { chlorhexidine } 0.5 \%\end{array}$ & $\begin{array}{c}\text { Augmentin } 625 \mathrm{mg}, \\
\text { GalaxoSmithKline Pharma, Viena, } \\
\text { Austria); Ibuflam } 600 \\
\text { (Zentiva, Lichtenstein) }\end{array}$ & $\begin{array}{l}\text { Postoperative control of the } \\
\text { pain and inflammatory } \\
\text { processes }\end{array}$ \\
\hline 9. & $\begin{array}{l}\text { Removal of the sutures at } \\
\text { 9-11 days postoperatively }\end{array}$ & & \\
\hline 10. & $\begin{array}{l}\text { Second stage surgery: } \\
\text { osteosynthesis screws removal } \\
\text { at } 4 \text { months postoperative }\end{array}$ & & \\
\hline
\end{tabular}

Prosthetic loading was carried out after 14-16 weeks following implants placement in the mandible. Each patient was included in a maintenance program consisting of oral hygiene and recall visits every 6 months.

\subsection{Evaluation of Clinical and Bone Parameters}

The evaluation of the preoperative clinical parameters and at 6 months follow-up was performed by one investigator (T.B.). Criteria for the success of S-GBR grafting procedure were as follows: absence of fistula; flow out of the particles of the graft material; chronic inflammation. Implant success was defined according to Buser criteria: absent pain; lack of implant mobility or recurrent peri-implant infection; absence of peri-implant radiolucency at 6 months post-loading [18].

The CBCT exam (Sirona Orthophos XG) was used to record width and osteodensity values of the implant sites. CBCT scanning conditions were a s follows: $85 \mathrm{kV}, 6 \mathrm{~mA}, 14.4 \mathrm{~s}$ irradiation time, $25-1025 \mu \mathrm{Sv}$ irradiation dose, and $1 \mathrm{~mm}$ slices thickness. CBCT images 
were stored in DICOM file. An independent radiologist that was not involved in the study performed all the bone parameters measurements (preoperative, 6 months follow-up).

Standardized measurements were taken for alveolar width preoperative and at 6 months postoperative. Implant sites width was measured before teeth extractions and 6 months after augmentation procedures. The osteodensity bone values were evaluated immediately after implant placement and at 6 months follow-up. Sidexis XG/ DVT (Densply/Sirona) software was used for the measurement of the width alveolar bone parameters at baseline and at 6 months follow-up. Width measurements were taken $3 \mathrm{~mm}, 5 \mathrm{~mm}$, and $10 \mathrm{~mm}$, respectively, from the crest at 3 intervals: the mesiodistal midpoint of the edentulous area and $3 \mathrm{~mm}$ mesial and distal to the midpoint. A mean value of width was calculated for each implant site preoperatively and at 6 months postoperatively. NNT Viewer/CT (NewTom) software was used to record the osteodensity values at baseline and at 6 months postoperative. The measurement of the preoperative osteodensity was performed immediately after implant placement and at 6 months follow-up. The bone density was measured in the areas adjacent to the implant, to the midpoint level.

\subsection{Statistical Analysis}

Statistical tests were used to compare the bone gain of the implant sites (width and osteodensity) at 6 months postoperative. The frequencies distributions were calculated for qualitative variables, while the averages and standard deviations were calculated for the quantitative variables. The normality of data distribution was checked with the Shapiro-Wilk test. The comparison of the quantitative variables between the test group and the control group was performed by using a $t$-test and the Mann-Whitney test. The comparison of the qualitative variables between the test group and the control group was performed by using the chi-square test. We tested whether the differences recorded between preoperative and postoperative values for the three parameters (width and osteodensity) were statistically significant. The Wilcoxon test was used for paired samples, as the values of the parameters do not comply with the law of normal distribution according to ShapiroWilk normality tests. The significance level was set at $p<0.05$. Statistical analysis was performed using SPSS version 27.0 for Windows (IBM, Armonk, NY, USA).

Intraoral view aspects and CBCT images of the implant sites, from a patient included in the test group, are presented in Figure 1a-o (reconstruction of the implant sites by S-GBR technique with porcine-derived xenograft material). 


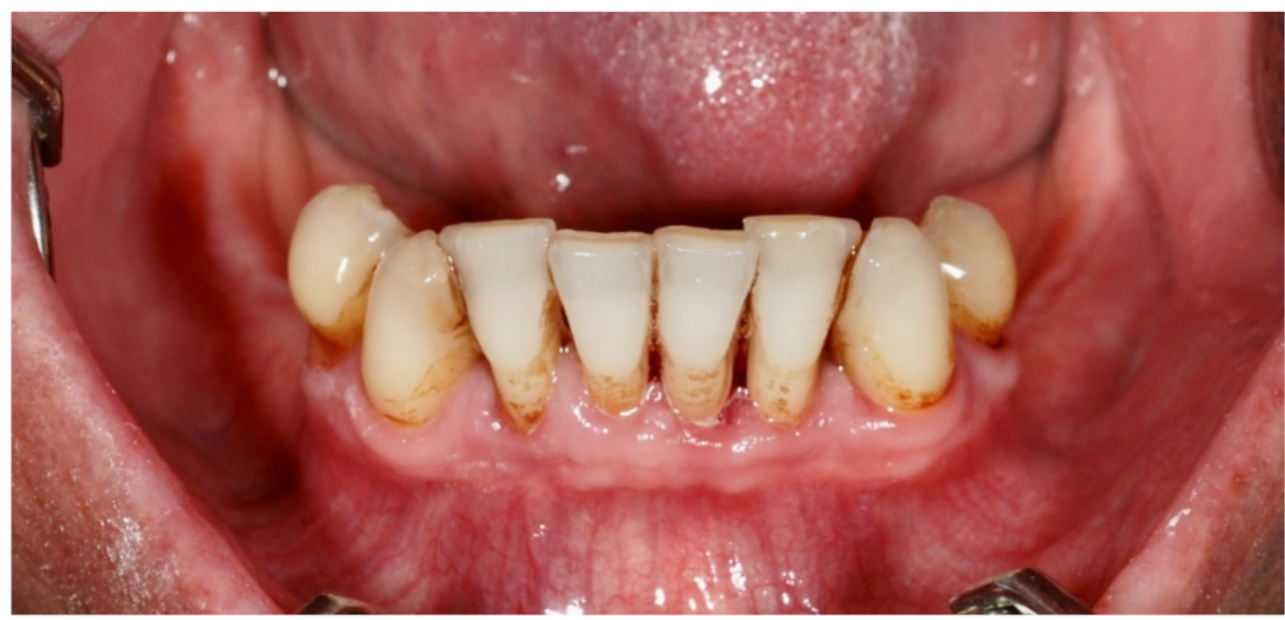

(a)

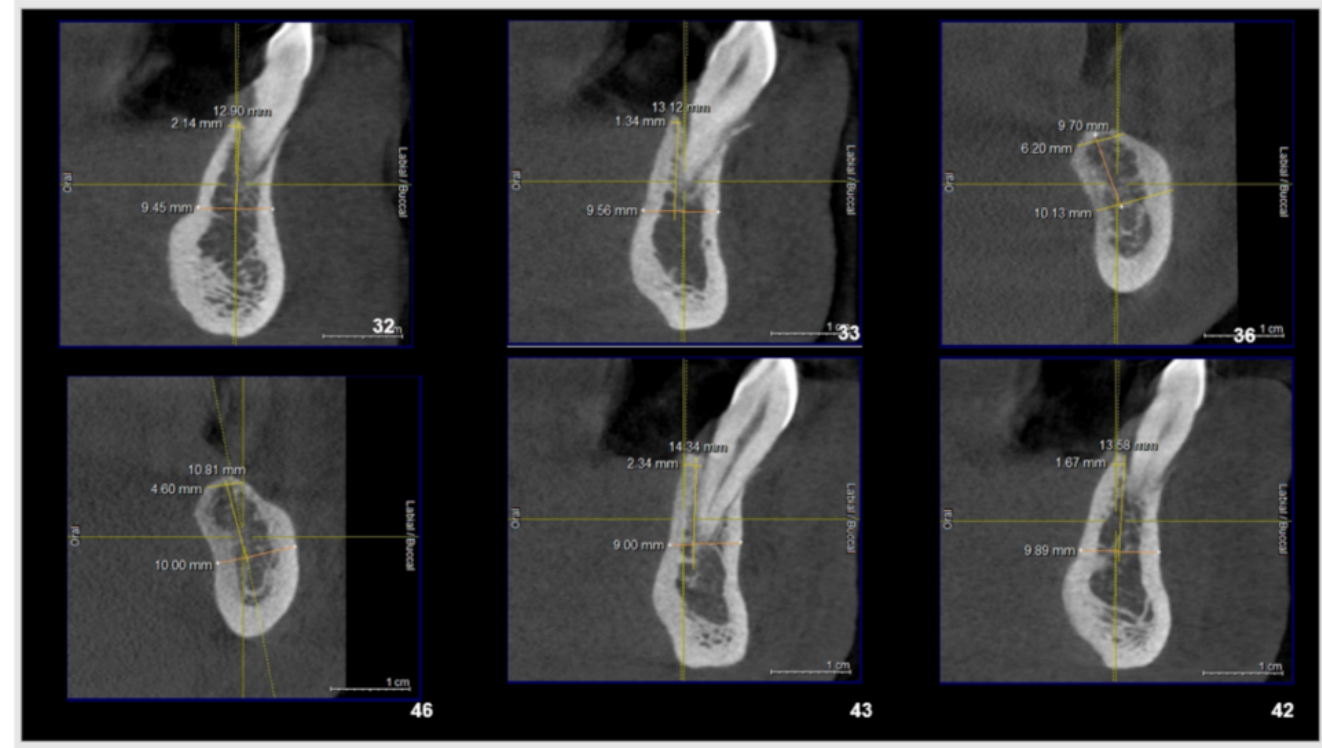

(b)

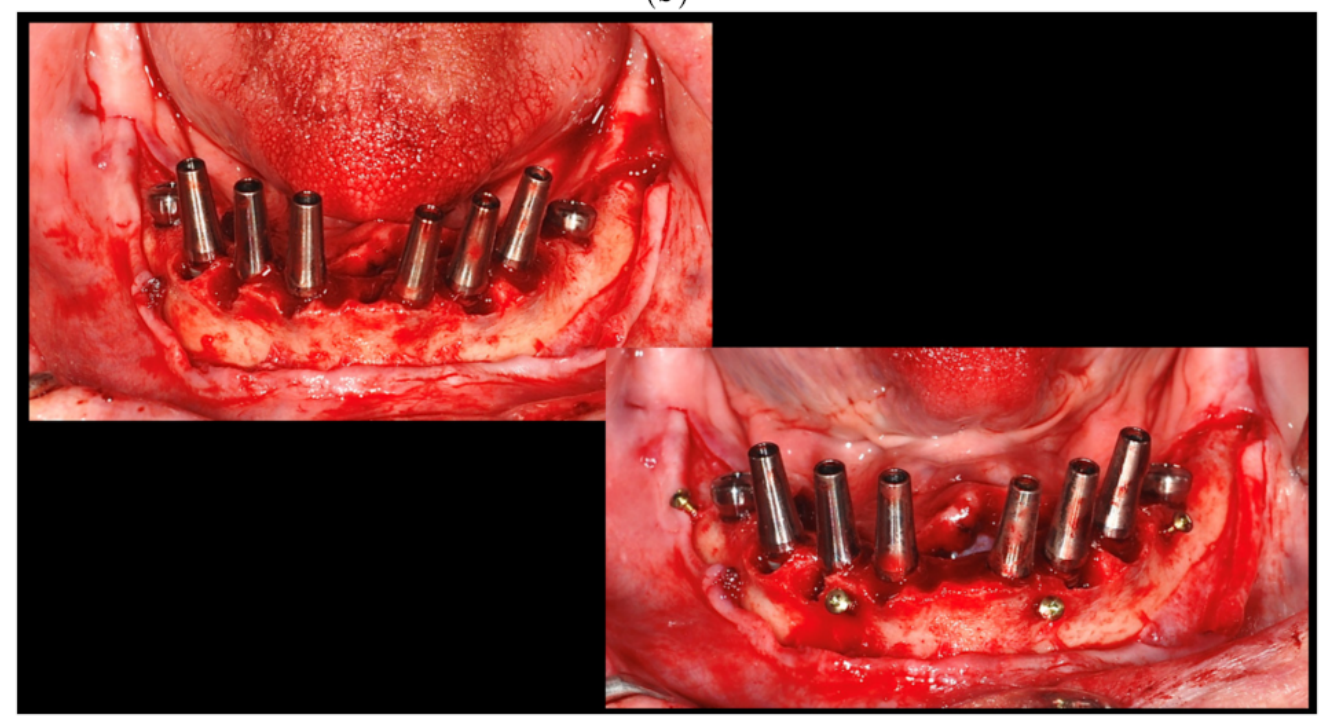

(c)

Figure 1. Cont. 


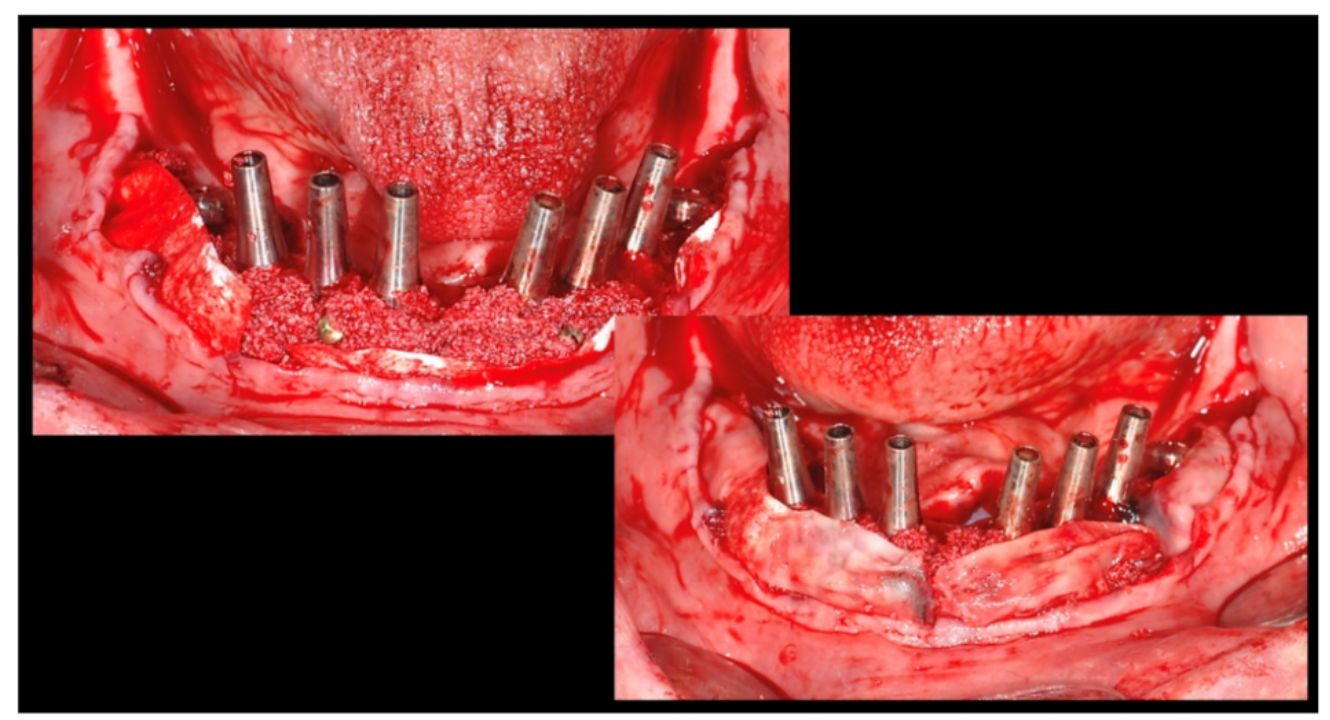

(d)

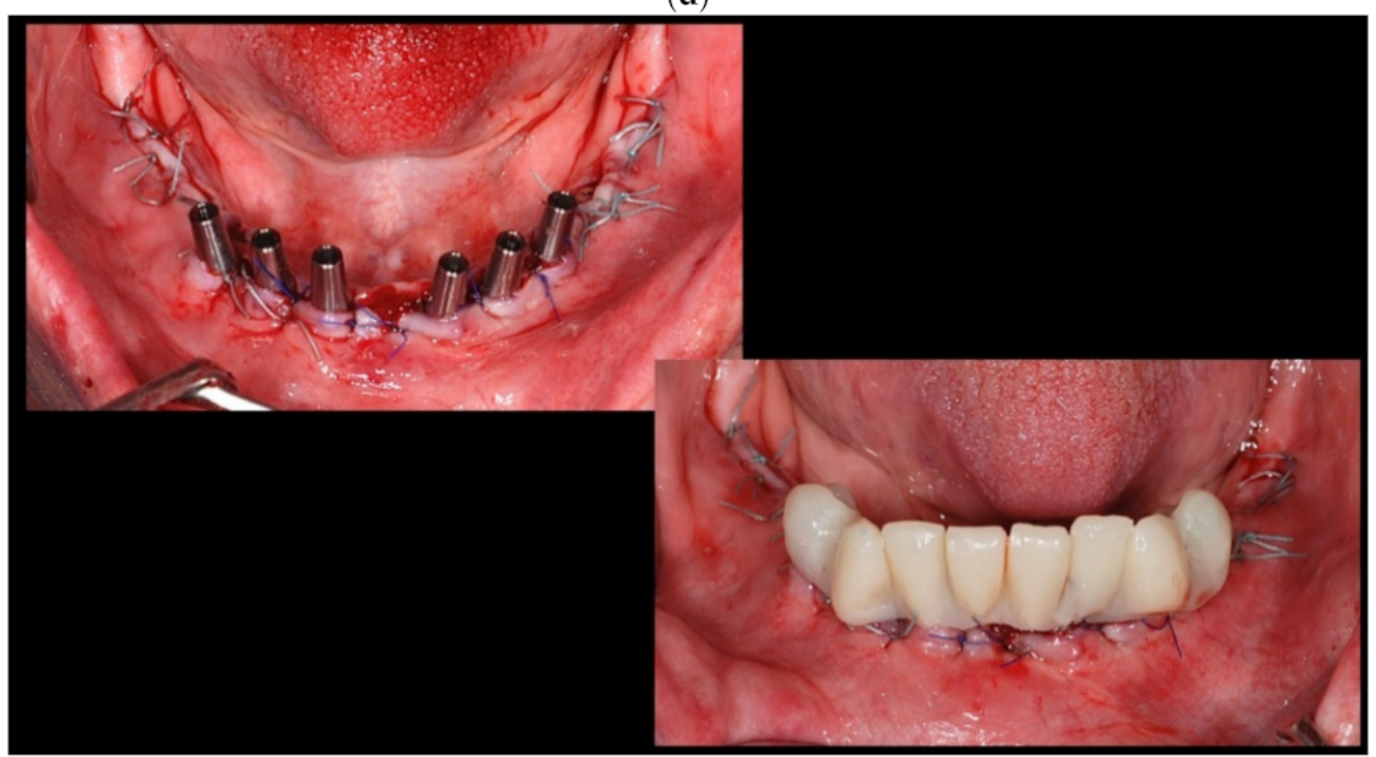

(e)

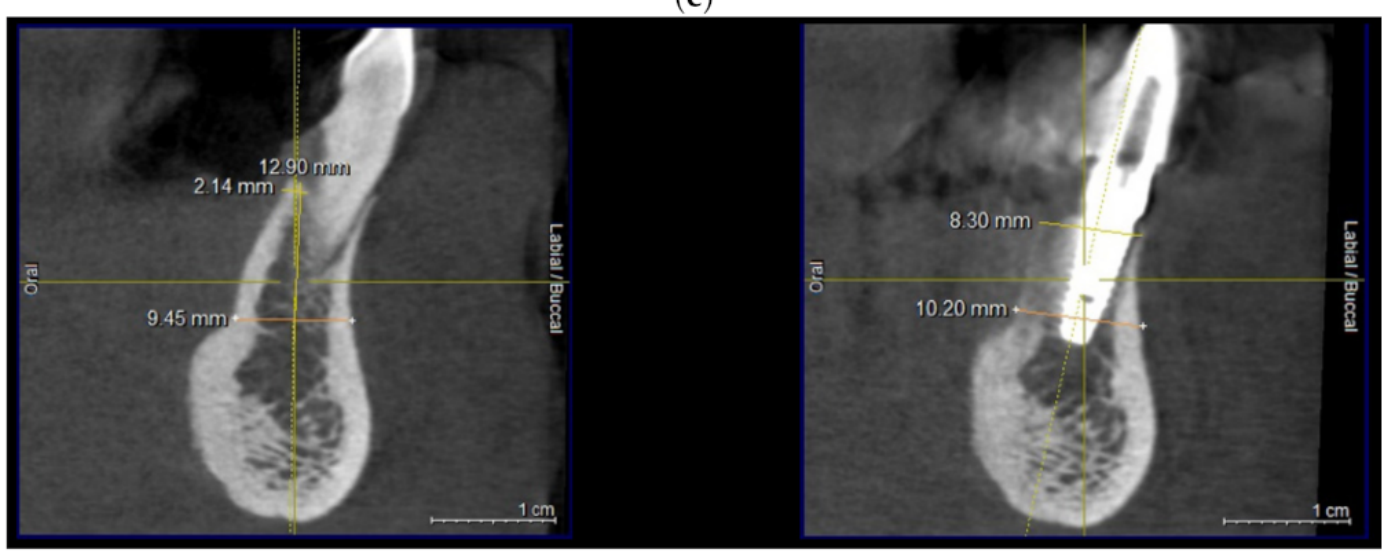

(f)

Figure 1. Cont. 


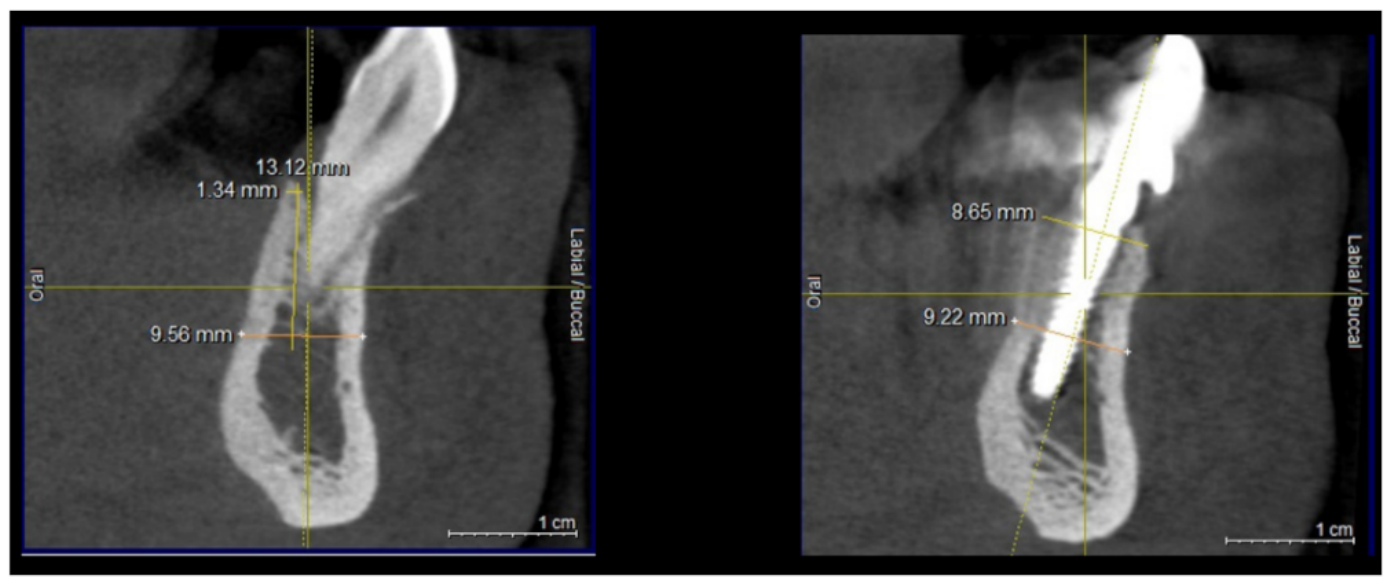

(g)

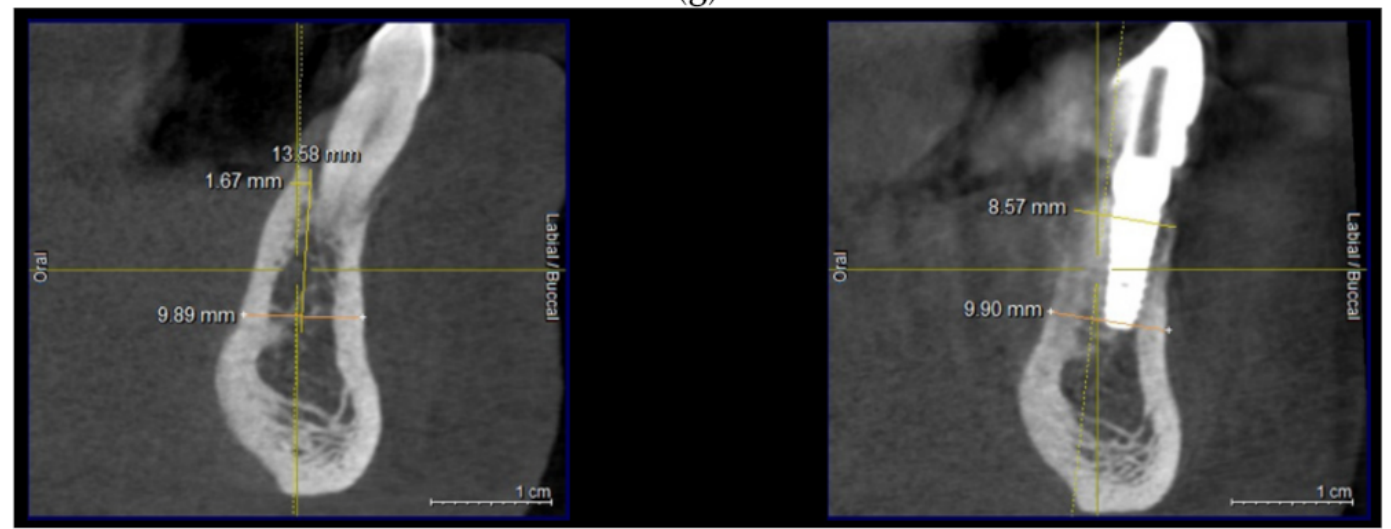

(h)

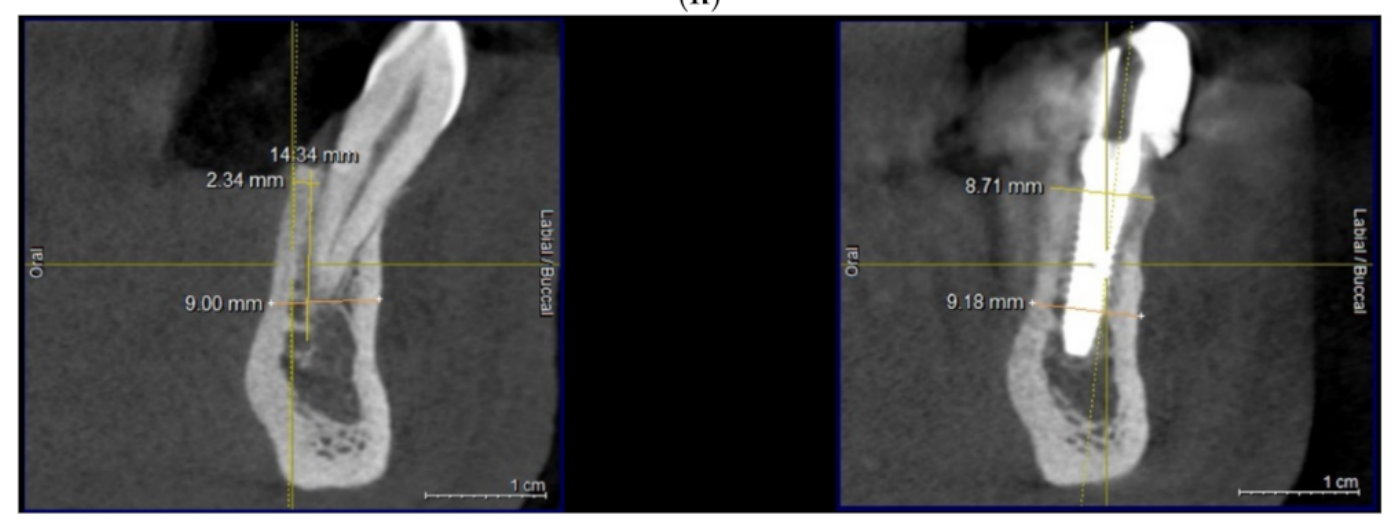

(i)

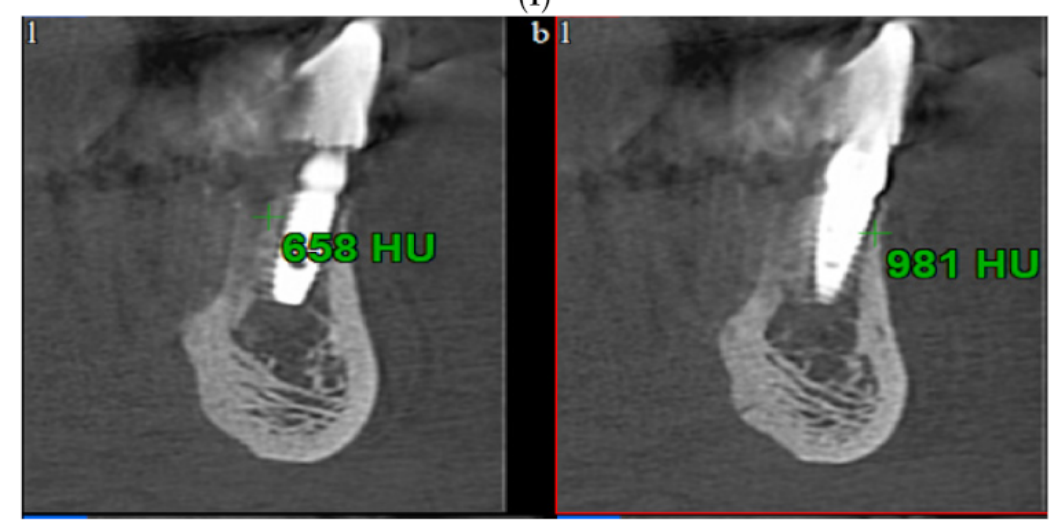

(j)

Figure 1. Cont. 


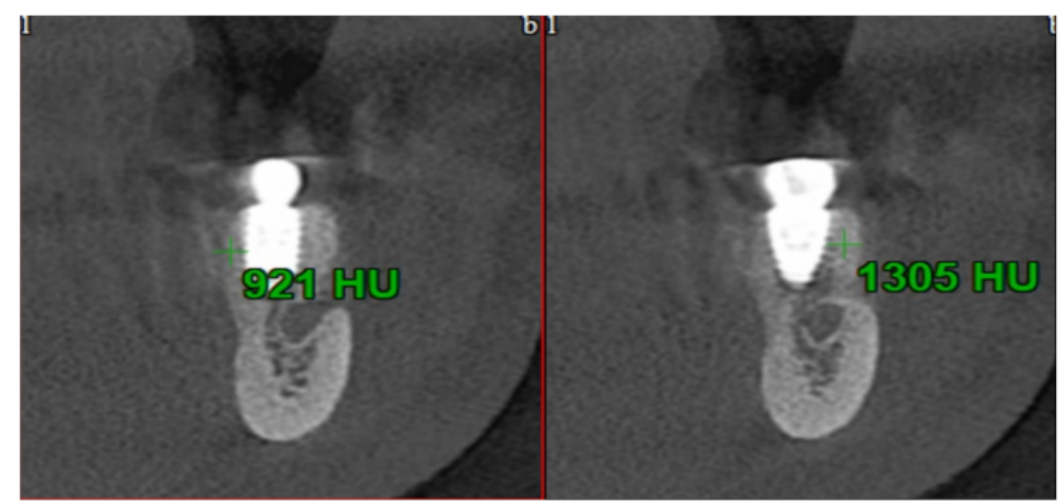

(k)

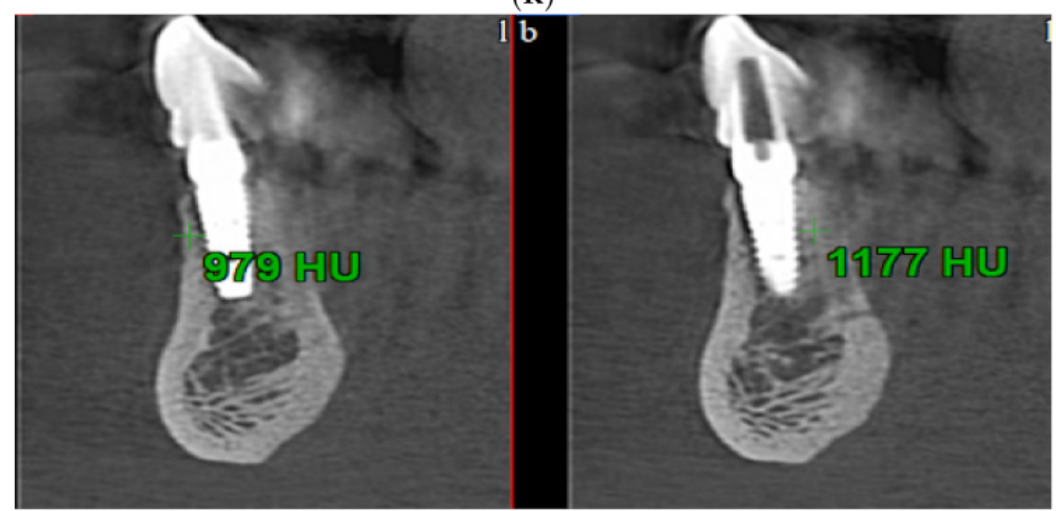

(1)

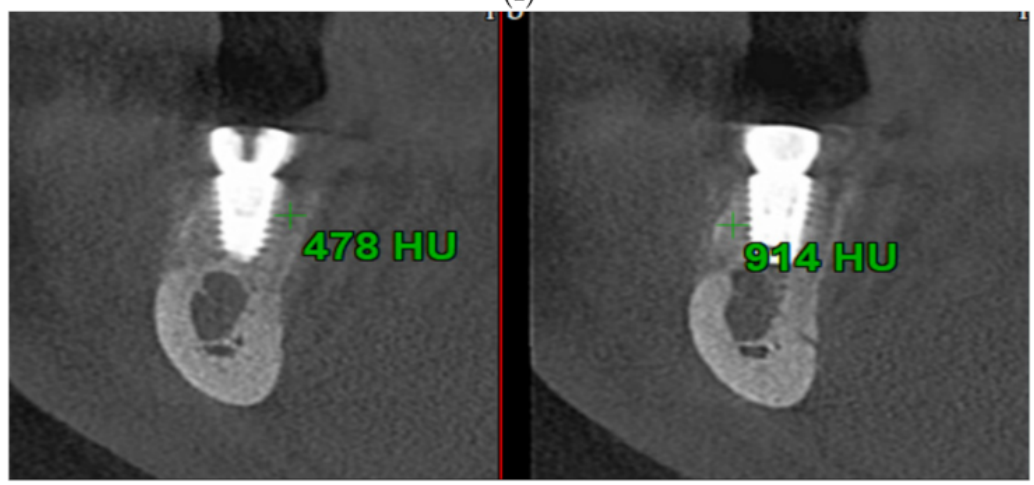

(m)

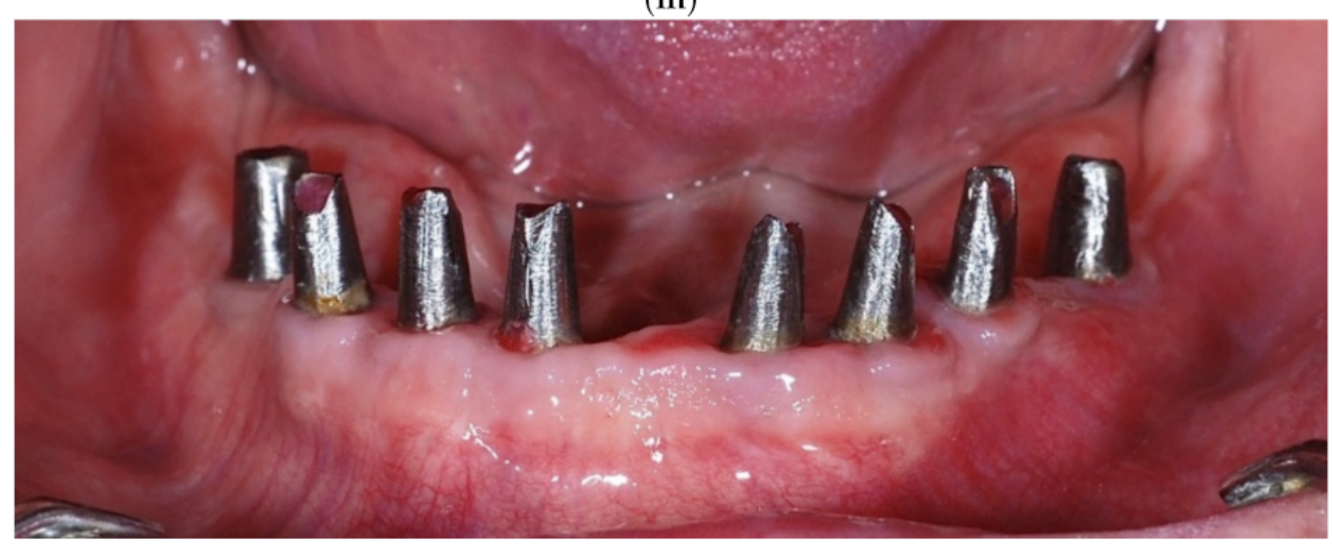

(n)

Figure 1. Cont. 


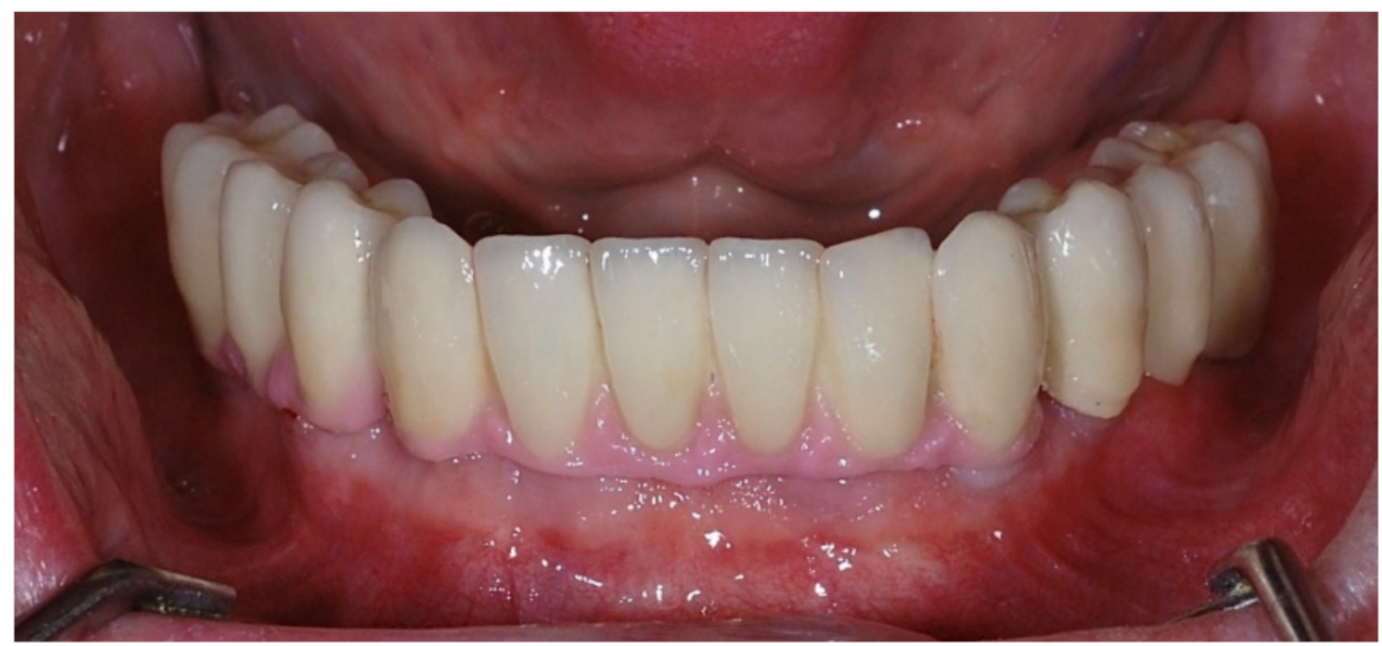

(o)

Figure 1. (a) A.C., aged 65. Preoperatory intraoral view. (b) Preoperative CBCT images and alveolar bone parameters measured with Sidexis XG/ DVT (Densply/Sirona) software. (c) Intraoral view after the insertion of osteosynthesis screws and implants. (d) Intraoral view after the mandibular alveolar reconstruction with S-GBR technique and porcine xenograft. (e) Postoperative intraoral view after wound suture and temporary loading. (f) Alveolar bone width values measured at baseline (left) and at 6 months follow-up with Sidexis XG/ DVT software (Densply/Sirona). (g) Alveolar bone width values measured at baseline (left) and at 6 months follow-up with Sidexis XG/ DVT software (Densply/Sirona). (h) Alveolar bone width values measured at baseline (left) and at 6 months follow-up with Sidexis XG/ DVT software (Densply/Sirona). (i) Alveolar bone width values measured at baseline (left) and at 6 months follow-up with Sidexis XG/DVT software (Densply/Sirona). (j) Alveolar bone osteodensity values measured at baseline (left) and at 6 months follow-up (right) (implant site 4.1). (k) Alveolar bone osteodensity values measured at baseline (left) and at 6 months follow-up (right) (implant site 4.5). (1) Alveolar bone osteodensity values measured at baseline (left) and at 6 months follow-up (right) (implant site 3.2). (m) Alveolar bone osteodensity values measured at baseline (left) and at 6 months follow-up (right) (implant site 3.5). (n) Preloading intraoral view. (o) Postloading intraoral view.

\section{Results}

In the first stage we compared, at the intra-group level, the average values of the bone gain (width and osteodensity) for sex, age groups, and the location of the augmented implant sites.

The bone gain (width) values for each group are presented in Figure $2 \mathrm{a}, \mathrm{b}$. In the control group (S-GBR + bovine xenograft), the bone gain (width) was higher in male patients $(4.5100 \mathrm{~mm}$ vs. $4.3150 \mathrm{~mm})$, age group $40-59$ years $(4.7225 \mathrm{~mm}$ vs. $4.1450 \mathrm{~mm})$, and the posterior dental group $(4.4954 \mathrm{~mm}$ vs. $4.1580 \mathrm{~mm})$. In the test group (S-GBR + porcine xenograft), the bone gain (width) was higher in female patients $(6.4885 \mathrm{~mm}$ vs. $5.2075 \mathrm{~mm})$, age group 60-79 $(6.5185 \mathrm{~mm}$ vs. $5.1750 \mathrm{~mm})$, and the posterior dental group (6.0971 mm vs. $5.3988 \mathrm{~mm})$.

The bone gain (osteodensity) values for each group are presented in Figure 3a,b. In the control group (S-GBR + bovine xenograft), the bone gain (osteodensity) was higher in female patients (319.90 HU vs. $4.3150 \mathrm{~mm}$ ), age group 40-59 years (303.00 HU vs. $255.90 \mathrm{HU})$, and the anterior dental group (334.60 HU vs. $254.61 \mathrm{HU}$ ). In the test group (S-GBR + porcine xenograft), the bone gain (osteodensity) was higher in male patients ( 268.50 vs. $241.07 \mathrm{HU}$ ), age group 40-59 years (279.91 HU vs. $230.53 \mathrm{HU}$ ), and the posterior dental group (270.70 HU vs. 219.25 HU). 


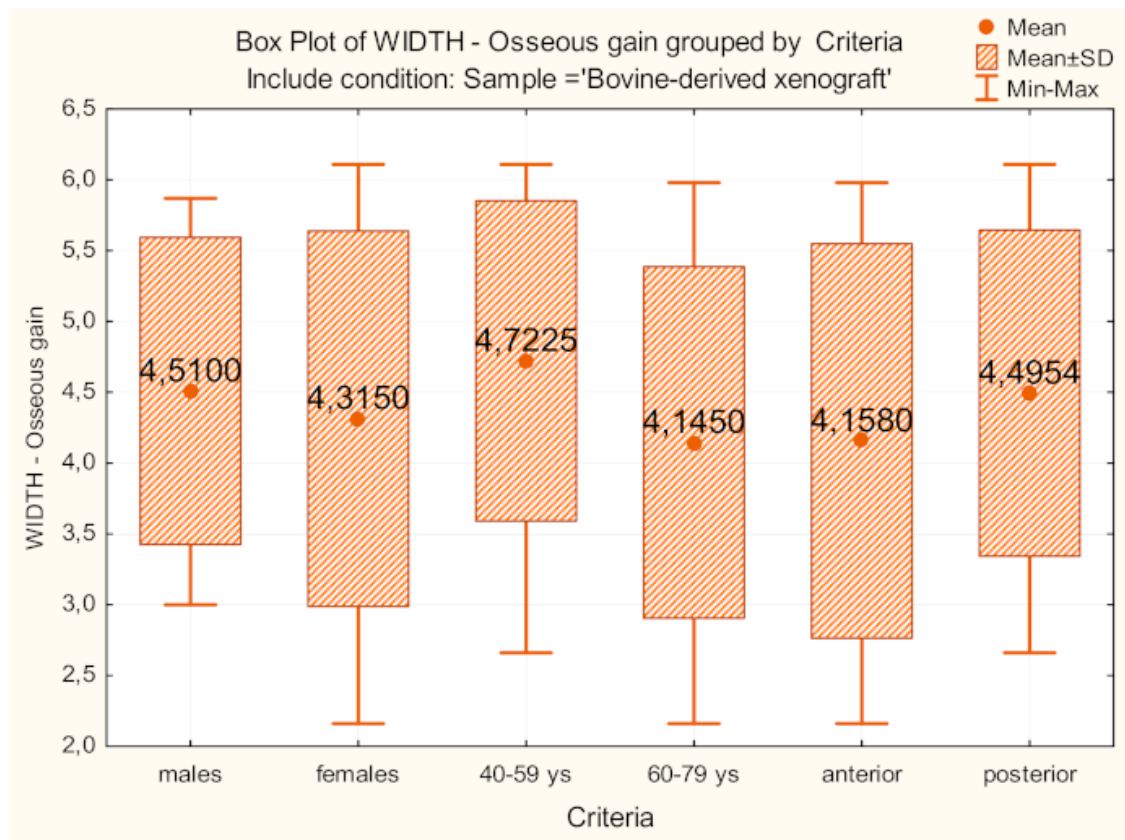

(a)

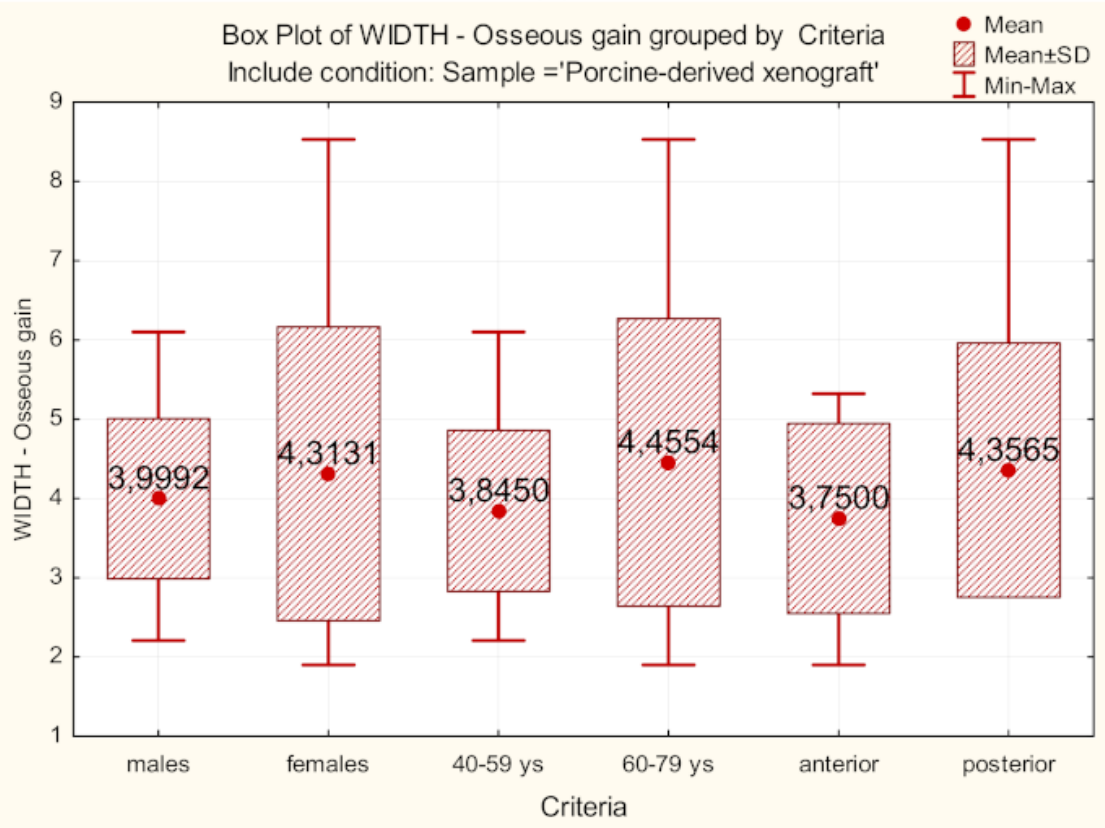

(b)

Figure 2. (a) Comparisons of bone gain (width) for sex, age groups, location of implant sites. Control group (S-GBR + bovine-derived xenograft). (b) Comparisons of bone gain (width) for sex, age groups, location of implant sites. Test group (S-GBR + porcine-derived xenograft). 


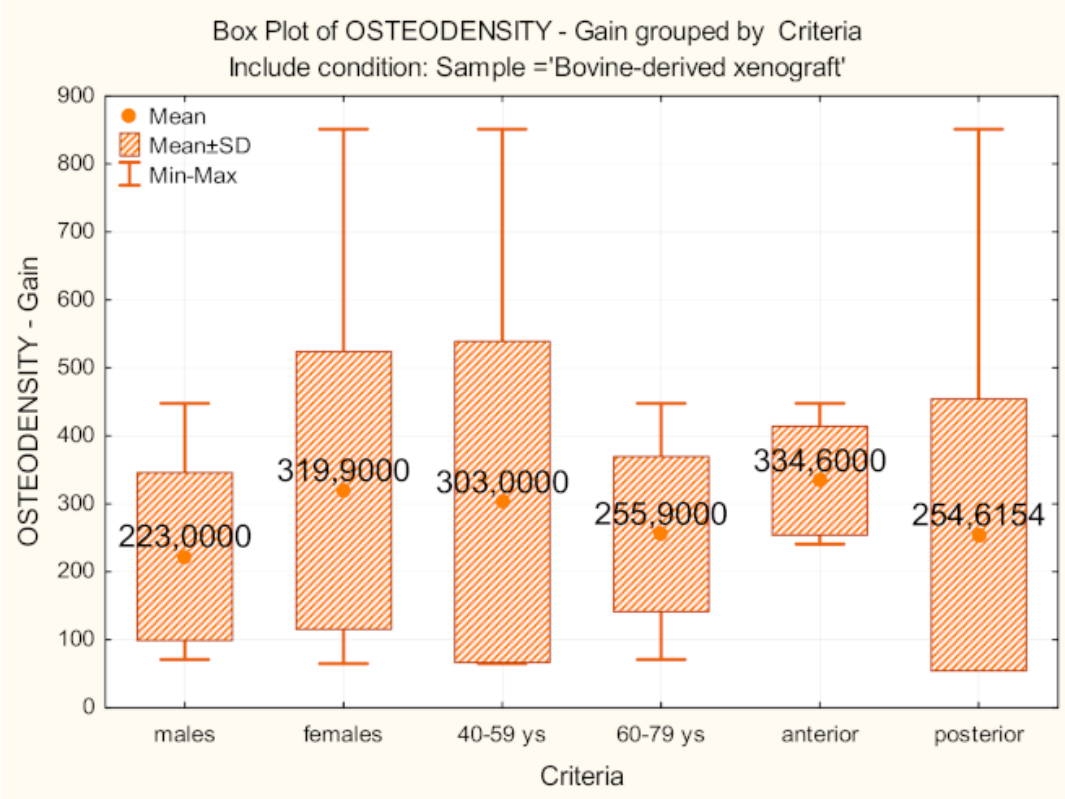

(a)

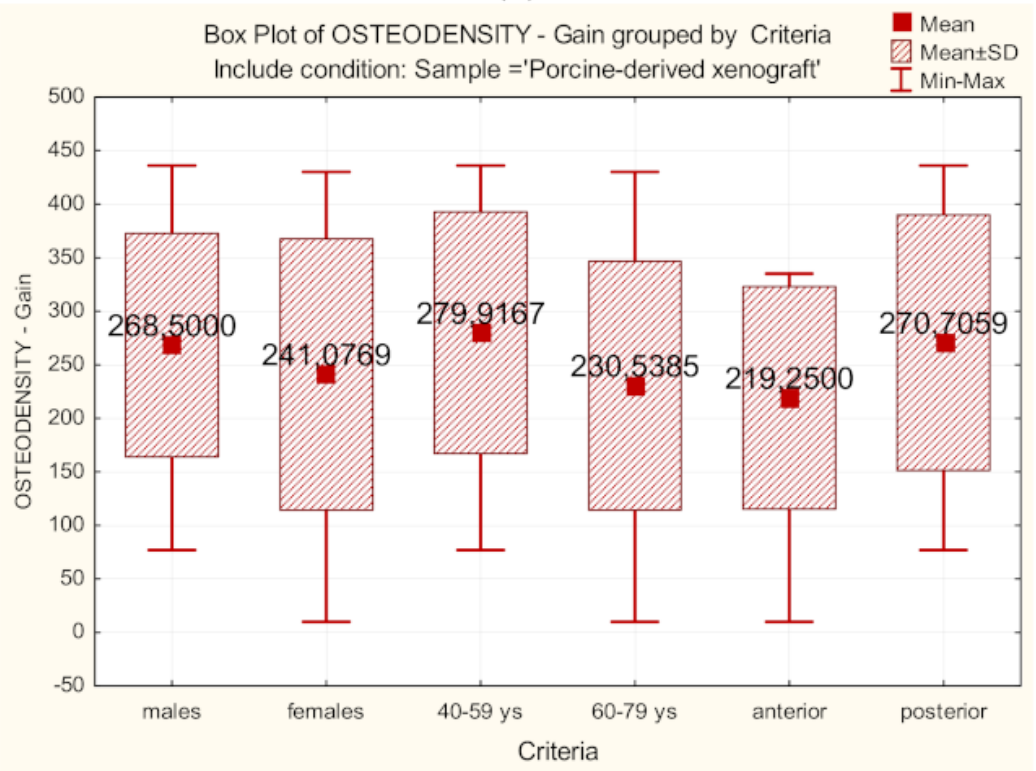

(b)

Figure 3. (a) Comparisons of bone gain (osteodensity) for sex, age groups, location of implant sites. Control group (S-GBR + bovine-derived xenograft). (b) Comparisons of bone gain (osteodensity) for sex, age groups, location of implant sites. Test group (S-GBR + porcine-derived xenograft).

Intergroup comparisons regarding the bone gain (width and osteodensity) are presented in Figure $4 \mathrm{a}, \mathrm{b}$. The mean values (control group vs. test group) are as follows: width (4.107 mm vs. $4.1624 \mathrm{~mm}$ ); osteodensity (276.83 HU vs. 254.24 HU). 


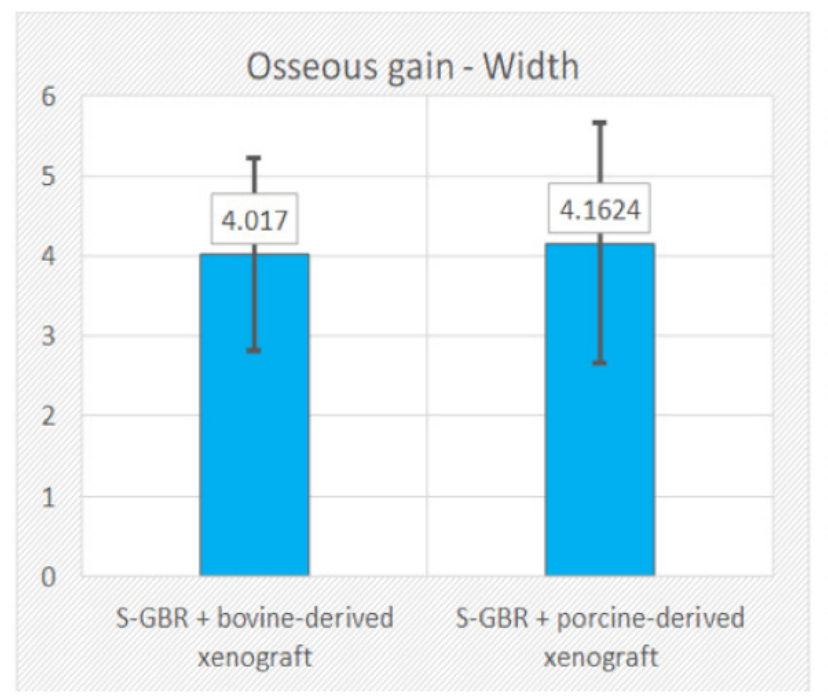

(a)

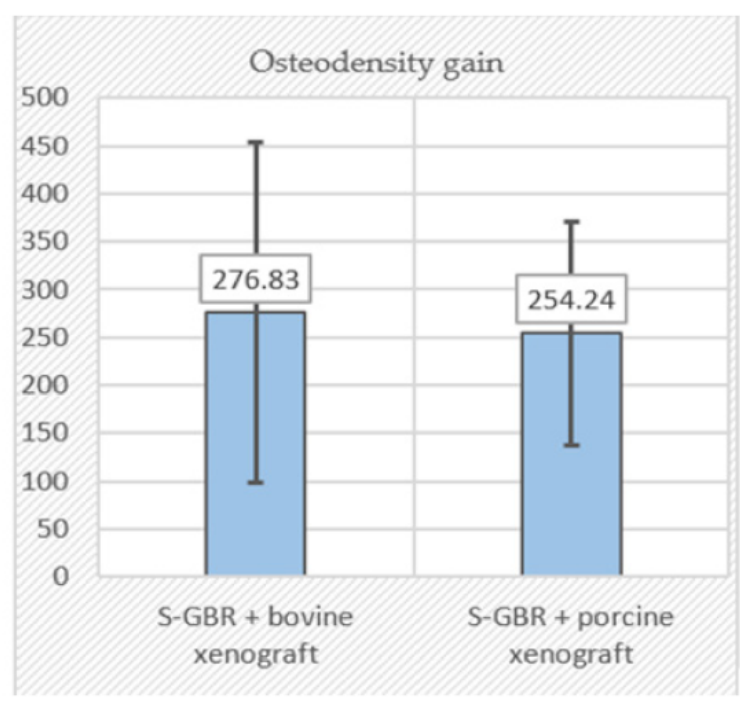

(b)

Figure 4. (a,b) Intergroup comparisons of bone gain (width, osteodensity) at 6 months follow-up. (S-GBR + bovine-derived xenograft group vs. S-GBR + porcine-derived xenograft group.).

The statistical analysis found the absence of statistically significant differences between the two groups regarding the bone gain at 6 months follow-up (width, osteodensity) (Table 4).

Table 4. Mann-Whitney test. Intergroup statistical comparisons (control vs. test group). (Bone gain: height, width, osteodensity).

\begin{tabular}{|c|c|c|c|c|c|}
\hline & \multirow{2}{*}{ Group } & \multicolumn{2}{|c|}{ Shapiro-Wilk Test } & \multicolumn{2}{|c|}{$\begin{array}{c}\text { Mann-Whitney/ } \\
\text { t-Student }\end{array}$} \\
\hline & & Statistics & Sig. $p$ & U/t Student & Sig. $p$ \\
\hline \multirow{2}{*}{$\begin{array}{l}\text { WIDTH- } \\
\text { Bone gain }\end{array}$} & Control & 0.938 & $0.045^{*}$ & 738,000 & 0.156 \\
\hline & Test & 0.890 & $0.000 * *$ & & \\
\hline \multirow{2}{*}{$\begin{array}{l}\text { OSTEODENSITY- } \\
\text { Bone gain }\end{array}$} & Control & 0.823 & $0.000^{* *}$ & 896,000 & 0.972 \\
\hline & Test & 0.964 & 0.125 & & \\
\hline
\end{tabular}

* Statistically significant, $p<0.05 ; * *$ Statistically highly significant, $p<0.01$.

\section{Discussions}

This study compared the bone gain parameters (width and osteodensity) after the reconstruction of the mandibular implant sites by the S-GBR technique and two categories of xenografts (bovine-derived and porcine-derived), followed by an immediate implant placement. Strict inclusion and exclusion criteria of the subjects were applied in our study, as the selection criteria of the patients could maximize the success rate of the augmentation procedures [9]. Moreover, the S-GBR technique avoided postgrafting complications due to the improper stabilization of the grafting materials and of postoperative infections. The GBR techniques are highly recommended for bone defects requiring horizontal augmentation, while a meta-analysis found no statistically significant differences between the various horizontal augmentation techniques [19].

We performed an immediate implant placement with simultaneous augmentation procedures, as the literature data report similar implant survival rates for immediate and delayed implant placements [20]. The survival rate of implants in the control and test groups was $100 \%$ at 6 months follow-up. The implant survival rate in the implant sites reconstructed by lateral ridge augmentation ranged from $97 \%$ to $100 \%$ at $6-12$ months of follow-up [21]. 
Suggestions were made for the complete replacement of the xenografts with autologous bone in the implant sites with medium and severe alveolar resorption [22]. However, we performed the augmentation procedures with a combination of autologous bone and xenografts in both the control group (bovine xenograft) and the test group (porcine xenograft) due to the limits of the autogenous bone as a unique graft material (i.e., morbidity at the donor site, lower availability, and dehiscence risk of the wound) [23]. Moreover, some patients prefer nonautogenous bone grafts with fewer postoperative healing days, less pain, and a shorter recovery time [24]. Xenografts have many benefits when used in guided bone regeneration techniques due to their biocompatibility, osteoconduction, the low resorption rates, as well as their ability to maintain the volume of the regenerative compartment [25]. Porcine-derived bone graft materials have been recently promoted as alternative materials to autogenous bone in augmentation procedures due to their good physicochemical properties, high biocompatibility, their osteoconductive properties, and the development of different formulations that stimulate bone regeneration processes [26,27].

Bone gains were recorded at 6 months follow-up in both groups of implant sites (control and test groups) for both measured parameters (width and osteodensity). The mean values found in our study for bone gains following the augmentation procedures and the immediate implant placement (S-GBR + bovine-derived xenograft vs. S-GBR + porcinederived xenograft) are as follows: width $(4.107 \mathrm{~mm}$ vs. $4.1624 \mathrm{~mm})$; osteodensity $(276.83 \mathrm{HU}$ vs. $254.24 \mathrm{HU}$ ). The horizontal bone gain (width) was similar and without significant statistical differences between the implant sites reconstructed by the S-GBR technique and the bovine-derived xenograft and those reconstructed by the S-GBR technique and the porcine-derived xenograft. However, the osteodensity gain was higher in the implant sites reconstructed with the bovine-derived xenograft, but without significant statistical differences in comparison with the test group. These results could be related to the differences related to the structure and the physicochemical properties between the two categories of the xenografts. The porcine-derived xenograft used in the personal study (Purgo, Purgos Biologics, Seongnam-si, Korea) has a high degree of porosity (78.4\%), a large specific surface area (SSA; $\left.69.9 \mathrm{~m}^{2} / \mathrm{g}\right)$, a high degree of surface roughness $(4.47 \mu \mathrm{m})$, and a significant percentage of pores with a diameter $<100-\mathrm{nm}$. The degree of porosity is higher than that detected in the case of the bovine-derived xenografts and very close to the porosity of the human trabecular bone $(79.3 \%)$, while the micropores and macropores play a crucial role in new bone formation [28]. The osteoblasts have higher proliferation rates, higher rates of alkaline phosphatase synthesis, and mineral deposition on the extracellular matrix if they adhere to surfaces with micropores less than $100 \mathrm{~nm}$ diameter [29]. The degree of hydrophilicity and the surface energy of the porcine-derived xenograft leads to high protein absorption rates, increased cell adhesion rates, and the stimulation of cell proliferation processes $[30,31]$.

The statistical tests determined the absence of significant statistical differences between the control and test groups at 6 months follow-up for all measured alveolar bone parameters. The average results of the horizontal bone gains (width) for the bovine-derived xenograft augmentation procedures obtained in our study were comparable with data reported by similar research [21,32-35]. Elnayef et al. (2018) have reported in a comprehensive review of the literature a net horizontal bone gain at follow-up of $2.86 \pm 0.23 \mathrm{~mm}$ [21] Troeltzsch et al. (2016) have reported in a systematic review a mean horizontal gain of $4.5 \pm 1.0 \mathrm{~mm}$ after alveolar bone augmentation techniques with mixtures of autogenous bone and xenogeneic grafting material [32]. Urban et al. (2013) have found an average value of $5.68 \mathrm{~mm}$ horizontal bone gain in the lateral ridge augmentation techniques performed with autogenous bone and bovine bone-derived xenografts [33]. Mordenfield et al. (2014) have reported for lateral ridge augmentation with bovine-derived xenograft and autogenous bone (90:10) a mean value of the horizontal bone gain of $5.7 \pm 1.0 \mathrm{~mm}$ [34]. De Santis et al. (2021) have found a mean horizontal gain of $3.6 \pm 0.8 \mathrm{~mm}$ and a mean vertical gain of $5.2 \pm 1.1 \mathrm{~mm}$ in the augmentation of the mandibular alveolar defects using a combination of autogenous bone and bovine xenografts [35]. Isik et al. (2021) have recorded, at 6 months 
follow-up, in a study that investigated the effectiveness of horizontal augmentation with the bovine-derived xenograft, the increase of the alveolar bone width with $1.34 \pm 0.14 \mathrm{~mm}$, $2.49 \pm 0.24 \mathrm{~mm}$, and $2.97 \pm 0.24 \mathrm{~mm}$ at $2 \mathrm{~mm}, 4 \mathrm{~mm}$, and $6 \mathrm{~mm}$, respectively, below to the implant shoulder [36]. Uzbek et al. (2014) have reported a significant increase of the osteodensity mean values $(390 \mathrm{HU})$ following the alveolar augmentation procedures with the bovine-derived xenograft [37]. A systematic review of the effectiveness of the natural and synthetic bone grafts used in the alveolar bone augmentation reported the absence of significant differences in the percentage of new bone between any two grafts and recommended the use of any category of xenografts in the enhancement of alveolar bone quality and volume prior to the insertion of the dental implants [38]. Moreover, a recent review performed by Zaki et al. (2021) has highlighted the contribution of the guided bone regeneration procedures used during the immediate implant placement in the decrease of the horizontal buccal bone resorption and the improvement of the peri-implant soft tissue esthetics [39].

Most studies that investigate the effectiveness of the horizontal and vertical alveolar augmentation procedures are especially focused on the quantitative parameters (i.e., the vertical and horizontal bone gain). Bone quality, changes in the bone density, the volume of the bone defect, the proportion between autogenous bones, other graft materials when mixed grafts are used, and the type of membrane should also be defined so that oral surgeons can make optimal decisions when performing alveolar bone regeneration techniques.

The limitations of this study are related to the low sample size, the low postoperative follow-up, and the possible subjective bias of the investigators during the stage of bone parameters measurements. Within these limitations, the data reported could contribute to a better understanding of the benefits of porcine-derived xenografts when used in guided bone regeneration techniques for the reconstruction of the implant sites and immediate implantation, as the literature data is scarce in studies comparing porcine-derived xenografts with other categories of additional materials, as well as in research focused on augmentation techniques combined with immediate implantation.

\section{Conclusions}

The horizontal bone and osteodensity gains in the porcine-derived group were similar and without significant statistical differences when compared with the implant sites reconstructed with the bovine-derived xenografts group at 6 months postoperatively. The reconstruction of the mandibular alveolar bone by the S-GBR technique and the porcinederived xenografts is a valid bone regeneration strategy for edentulous patients with moderate/severe horizontal resorption of the mandibular alveolar bone.

Author Contributions: Conceptualization, R.T., B.T. and D.M.D.E.; data curation, R.T. and B.T.; formal analysis, C.D.; methodology, D.M.D.E.; resources, D.A.-F. and C.G.S.; software, C.D.; supervision, D.A.-F., R.D. and C.G.S.; validation, R.D. and C.G.S.; visualization, D.A.-F., R.T. and B.T.; writing—original draft, R.T. and B.T.; writing—review and editing, R.T. and B.T. All authors have read and agreed to the published version of the manuscript.

Funding: This research was not funded by any grant.

Institutional Review Board Statement: Not applicable.

Informed Consent Statement: Informed consent was obtained from all subjects involved in the study.

Data Availability Statement: The data presented in this study are available on request from the corresponding authors.

Conflicts of Interest: The authors declare no conflict of interest. 


\section{References}

1. Guillaume, B. Dental implants: A review. Morphologie 2016, 100, 189-198. [CrossRef] [PubMed]

2. Mittal, Y.; Jindal, G.; Garg, S. Bone manipulation procedures in dental implants. Indian J. Dent. 2016, 7, 86-94. [CrossRef] [PubMed]

3. Huang, X.; Liu, X.; Shang, Y.; Qiao, F.; Chen, G. Current trends in research on bone regeneration: A bibliometric analysis. BioMed Res. Int. 2020, 2020, 1-12. [CrossRef]

4. Zhao, R.; Yang, R.; Cooper, P.; Khurshid, Z.; Shavandi, A.; Ratnayake, J. Bone grafts and substitutes in dentistry: A review of current trends and developments. Molecules 2021, 26, 3007. [CrossRef] [PubMed]

5. Cha, H.-S.; Kim, J.-W.; Hwang, J.-H.; Ahn, K.-M. Frequency of bone graft in implant surgery. Maxillofac. Plast. Reconstr. Surg. 2016, 38, 1-4. [CrossRef]

6. Törok, B.; Törok, R.; Forna, N. Study regarding share of peri-implant bone augmentation techniques and materials. Rom. J. Oral Rehab. 2020, 12, 88-96.

7. Mitrea, M.; Niculescu, S.; Dmor, A.; Walid, E.A.H.; Florea, C.; Săveanu, I.C.; Balcos, C.; Forna, N.C. Esthetic rehabilitation with implants-supported fixed dentures after periodontitis. Rom. J. Oral Rehab. 2021, 13, 102-113.

8. Sammartino, G.; Bernard, J.P. A clinical round table about the treatment of the severely resorbed posterior mandible. Part 1: Challenges, endeavor and perspectives. POSEIDO 2013, 1, 65-67.

9. Moy, P.K.; Aghaloo, T. Risk factors in bone augmentation procedures. Periodontol. 2000 2019, 81, 76-90. [CrossRef]

10. Tolstunov, L.; Hamrick, J.F.E.; Broumand, V.; Shilo, D.; Rachmiel, A. Bone augmentation techniques for horizontal and vertical alveolar ridge deficiency in oral implantology. Oral Maxillofac. Surg. Clin. North. Am. 2019, 31, 163-191. [CrossRef]

11. Chiapasco, M.; Casentini, P.; Zaniboni, M. Bone augmentation procedures in implant dentistry. Int. J. Oral Maxillofac. Implant. 2009, 24, 237-259.

12. Toeroek, R.; Dohan Ehrenfest, D.M. The concept of Screw-Guided Bone Regeneration (S-GBR). Part 2: S-GBR in the severely resorbed preimplant posterior mandible using bone xenograft and Leukocyte and Platelet-Rich Fibrin (L-PRF): A 5-year follow-up. POSEIDO 2013, 1, 85-92.

13. Török, B.; Török, R.; Ehrenfest, D.D.; Agop-Forna, D.; Dascălu, C.; Forna, N. Study of immediate implants placed in mandibular alveolar bone reconstructed with screw-guided bone regeneration technique: A 24-months follow-up. Appl. Sci. 2021, 11, 6054. [CrossRef]

14. Kim, Y.; Rodriguez, A.E.; Nowzari, H. The risk of prion infection through bovine grafting materials. Clin. Implant Dent. Relat. Res. 2016, 18, 1095-1102. [CrossRef] [PubMed]

15. Rodriguez, A.E.; Nowzari, H. The long-term risks and complications of bovine-derived xenografts: A case series. J. Indian Soc. Periodontol. 2019, 23, 487-492. [CrossRef] [PubMed]

16. Salamanca, E.; Lee, W.-F.; Lin, C.-Y.; Huang, H.-M.; Lin, C.-T.; Feng, S.-W.; Chang, W.-J. A novel porcine graft for regeneration of bone defects. Materials 2015, 8, 2523-2536. [CrossRef]

17. Bracey, D.N.; Seyler, T.M.; Jinnah, A.H.; Lively, M.O.; Willey, J.S.; Smith, T.L.; Van Dyke, M.E.; Whitlock, P.W. A Decellularized porcine xenograft-derived bone scaffold for clinical use as a bone graft substitute: A critical evaluation of processing and structure. J. Funct. Biomater. 2018, 9, 45. [CrossRef]

18. Buser, D.; Mericske-Stern, R.; Dula, K.; Lang, N.P. Clinical experience with one-stage, non-submerged dental implants. Adv. Dent. Res. 1999, 13, 153-161. [CrossRef]

19. Esposito, M.; Grusovin, M.G.; Felice, P.; Karatzopoulos, G.; Worthington, H.; Coulthard, P. The efficacy of horizontal and vertical bone augmentation procedures for dental implants: A cochrane systematic review. Evid.-Based Pract. Towar. Optim. Clin. Outcomes 2010, 2, 195-218. [CrossRef]

20. Wessing, B.; Lettner, S.; Zechner, W. Guided bone regeneration with collagen membranes and particulate graft materials: A systematic review and meta-analysis. Int. J. Oral Maxillofac. Implant. 2018, 33, 87-100. [CrossRef]

21. Elnayef, B.; Porta, C.; del Amo, F.S.L.; Mordini, L.; Gargallo-Albiol, J.; Hernández-Alfaro, F. The fate of lateral ridge augmentation: A systematic review and meta-analysis. Int. J. Oral Maxillofac. Implant. 2018, 33, 622-635. [CrossRef] [PubMed]

22. Elakkiya, S.; Ramesh, A.S.; Prabhu, K. Systematic analysis on the efficacy of bone enhancement methods used for success in dental implants. J. Indian Prosthodont. Soc. 2017, 17, 219-225. [CrossRef]

23. Herford, A.S.; Nguyen, K. Complex bone augmentation in alveolar ridge defects. Oral Maxillofac. Surg. Clin. North. Am. 2015, 27, 227-244. [CrossRef] [PubMed]

24. Chavda, S.; Levin, L. Human studies of vertical and horizontal alveolar ridge augmentation comparing different types of bone graft materials: A systematic review. J. Oral Implant. 2018, 44, 74-84. [CrossRef] [PubMed]

25. Li, J.; Xuan, F.; Choi, B.H.; Jeong, S.M. Minimally invasive ridge augmentation using xenogenous bone blocks in an atrophied posterior mandible: A clinical and histological study. Implantol. Dent. 2013, 22, 112-116. [CrossRef]

26. Falacho, R.; Palma, P.; Marques, J.; Figueiredo, M.; Caramelo, F.; Dias, I.; Viegas, C.; Guerra, F. Collagenated porcine heterologous bone grafts: Histomorphometric evaluation of bone formation using different physical forms in a rabbit cancellous bone model. Molecules 2021, 26, 1339. [CrossRef]

27. Salamanca, E.; Hsu, C.-C.; Huang, H.-M.; Teng, N.-C.; Lin, C.-T.; Pan, Y.-H.; Chang, W.-J. Bone regeneration using a porcine bone substitute collagen composite in vitro and in vivo. Sci. Rep. 2018, 8, 1-8. [CrossRef] 
28. Lee, D.S.; Pai, Y.; Chang, S. Physicochemical characterization of InterOss ${ }^{\circledR}$ and Bio-Oss ${ }^{\circledR}$ anorganic bovine bone grafting ma-terial for oral surgery: A comparative study. Mater. Chem. Phys. 2014, 146, 99-104. [CrossRef]

29. Webster, T.J.; Ergun, C.; Doremus, R.H.; Siegel, R.W.; Bizios, R. Enhanced functions of osteoblasts on nanophase ceramics. Biomaterials 2000, 21, 1803-1810. [CrossRef]

30. Kubies, D.; Himmlová, L.; Riedel, T.; Chánová, E.; Balík, K.; Douděrová, M.; Bártová, J.; Pesakova, V.J.P.R. The interaction of osteoblasts with bone-implant materials: The effect of physicochemical surface properties of implant materials. Physiol. Res. 2011, 60, 95-111. [CrossRef]

31. Rupp, F.; Gittens, R.A.; Scheideler, L.; Marmur, A.; Boyan, B.D.; Schwartz, Z.; Geis-Gerstorfer, J. A review on the wettability of dental implant surfaces I: Theoretical and experimental aspects. Acta Biomater. 2014, 10, 2894-2906. [CrossRef] [PubMed]

32. Troeltzsch, M.; Troeltzsch, M.; Kauffmann, P.; Gruber, R.; Brockmeyer, P.; Moser, N.; Rau, A.; Schliephake, H. Clinical efficacy of grafting materials in alveolar ridge augmentation: A systematic review. J. Cranio-Maxillofac. Surg. 2016, 44, 1618-1629. [CrossRef] [PubMed]

33. Urban, I.A.; Nagursky, H.; Lozada, J.L.; Nagy, K. Horizontal ridge augmentation with a collagen membrane and a combination of particulated autogenous bone and anorganic bovine bone-derived mineral: A prospective case series in 25 patients. Int. J. Periodontics Restor. Dent. 2013, 33, 299-307. [CrossRef] [PubMed]

34. Mordenfeld, A.; Johansson, C.B.; Albrektsson, T.; Hallman, M. A randomized and controlled clinical trial of two different compositions of deproteinized bovine bone and autogenous bone used for lateral ridge augmentation. Clin. Oral Implant. Res. 2014, 25, 310-320. [CrossRef]

35. De Santis, D.; Gelpi, F.; Verlato, G.; Luciano, U.; Torroni, L.; Antonucci, N.; Bernardello, F.; Zarantonello, M.; Nocini, P. Digital customized titanium mesh for bone regeneration of vertical, horizontal and combined defects: A case series. Medicine 2021, 57, 60 . [CrossRef]

36. Işı1k, G.; Yüce, M.Ö.; Koçak-Topbaş, N.; Günbay, T. Guided bone regeneration simultaneous with implant placement using bovine-derived xenograft with and without liquid platelet-rich fibrin: A randomized controlled clinical trial. Clin. Oral Investig. 2021, 25, 5563-5575. [CrossRef]

37. Uzbek, U.H.; Rahman, S.A.; Alam, M.K.; Gillani, S.W. Bone forming potential of an-organic bovine bone graft: A cone beam CT study. J. Clin. Diagn Res. 2014, 8, 73-76. [CrossRef]

38. Papageorgiou, S.N.; Papageorgiou, P.; Deschner, J.; Götz, W. Comparative effectiveness of natural and synthetic bone grafts in oral and maxillofacial surgery prior to insertion of dental implants: Systematic review and network meta-analysis of parallel and cluster randomized controlled trials. J. Dent. 2016, 48, 1-8. [CrossRef]

39. Zaki, J.; Yusuf, N.; El-Khadem, A.; Scholten, R.J.P.M.; Jenniskens, K. Efficacy of bone-substitute materials use in immediate dental implant placement: A systematic review and meta-analysis. Clin. Implant Dent. Relat. Res. 2021, 23, 506-519. [CrossRef] 